\title{
Weaving Entrepreneurially Minded Learning Throughout a Civil Engineer- ing Curriculum
}

\section{Dr. Andrea L. Welker, Villanova University}

Dr. Andrea L. Welker, PE, is the Associate Dean for Academic Affairs and a professor in the department of Civil and Environmental Engineering at Villanova University. Dr. Welker teaches a variety of geotechnical undergraduate and graduate classes. Her research focuses on the geotechnical aspects of stormwater control measures and the use of recycled materials in plastic pipes. In addition to teaching and performing research, she is the senior director of the Civil Engineering Division for ASEE.

\section{Dr. Kristin M. Sample-Lord, Villanova University}

Dr. Joseph Robert Yost, Villanova University

Joseph Robert Yost is a Professor in the Civil and Environmental Engineering Department at Villanova University, where he teaches undergraduate and graduate courses in structural mechanics and design. 


\title{
Weaving Entrepreneurially Minded Learning Throughout a Civil Engineering Curriculum
}

\begin{abstract}
The Kern Family Foundation has provided funding to Villanova University to implement the Kern Entrepreneurial Engineering Network (KEEN) initiative. This nearly decade-old initiative seeks to instill concepts of Entrepreneurially Minded Learning (EML) into the undergraduate engineering curriculum. EML emphasizes educating the "whole engineer” by supplementing traditional engineering theory with nontechnical concepts related to curiosity, connections, and creating value (the three Cs). "Curiosity” encourages students to investigate and question the society that surrounds them within the context of the technical material they are learning in class. In short, it encourages students to be problem seekers and definers as opposed to just problem solvers. Students are then ready to make "Connections" to synthesize new and old knowledge to create innovative solutions to problems. Lastly, "Creating Value" is about improving society and quality of life by creatively applying their engineering skills. It is important to note that this approach to education is not about creating start-ups or commercial products, rather, it is a way to foster inventive thinking. Nearly half of the faculty members in the Civil and Environmental Engineering (CEE) department have participated in KEEN workshops that focus on implementation of EML in their respective courses. These faculty have woven EML throughout the CEE curriculum to ensure that students have assignments that relate to the three Cs every semester from freshman to senior year. These assignments are also used to fulfill ABET and ASCE Civil Engineering Program Criteria. This paper will describe class assignments for courses with EML content, extra- and co-curricular EML activities, the relationship between EML and ABET criterion 3 and the ASCE Civil Engineering Program Criteria, and provide thoughts on linking EML to educational assessment.

\section{Introduction}

Entrepreneurially Minded Learning (EML) is an approach to learning that emphasizes the three Cs: curiosity, connections, and creating value. This approach to learning includes in and out of class experiences to develop critical professional skills. The skills emphasized include working well in team settings, thinking critically and creatively, communicating effectively, demonstrating persistence in the face of failure, bringing value to customers, committing to social responsibility, and appreciating the role of individual liberties and freedom in success.

Villanova University began its partnership with the Kern Family Foundation in 2007. That first grant supported implementation of the Kern Entrepreneurial Engineering Network (KEEN) initiative. Subsequent grants from the Kern Family Foundation have supported intrapreneurship development and intercollegiate entrepreneurship opportunities, faculty training to attain the goal of including EML into at least half of the engineering classes in the College, and creation of an Engineering Entrepreneurship minor that can be attained during the school year or through a single summer-intensive program.
\end{abstract}


The training workshops for faculty at Villanova University are held each summer. Approximately eight faculty members from all four departments participate each year. At the time of writing about 1/3 of the faculty in the Civil and Environmental Engineering (CEE) department have participated in these workshops. To encourage "buy-in" from the departments and to ensure better integration of EML, each department has a designated "EML Champion" that is a veteran of the EML faculty workshop and has implemented EML into their own classes. At Villanova University, the reticence on the part of some CEE faculty could be attributed to several misconceptions: EML is about start-ups, making widgets, and the faculty does not have the appropriate experience. The responses that had the largest impact to dispel these misconceptions were:

- EML is not about start-ups and widgets: it is about thinking creatively and creating value for society, which are critical aspects of being a civil engineer. Furthermore, many of the graduates from Villanova University work for or own consulting firms and need to understand how they add value to their company, their customers, and society.

- Faculty are naturally entrepreneurial: they write grants and successfully convince others to sponsor their work, build research teams, communicate the results broadly, find creative ways to teach new material, and make connections to other classes in the curriculum.

The literature provides several examples and case studies of implementation of EML into engineering curriculums ${ }^{1,2,3}$; however, the literature is sparser on the implementation of EML into Civil Engineering curriculums. This paper is meant to provide examples on how EML can be woven throughout a Civil Engineering curriculum and how it relates to the proposed ABET criteria and the current Civil Engineering Program Criteria. In addition, extra and co-curricular programs at the university are described. Admittedly, assessment of EML at Villanova has been weak, however, several ideas of how EML could be assessed in the future are provided.

\section{Institutional Background}

Villanova University is a comprehensive Roman Catholic institution founded in 1842 by the friars of the Order of St. Augustine. The University welcomes students of all faiths and is located in a western suburb of Philadelphia. The University offers a wide variety of degree programs through six colleges: the College of Liberal Arts and Sciences, the School of Business, the College of Engineering, the College of Nursing, the College of Professional Studies, and the Charles Widger School of Law. The College of Engineering offers five BS and nine MS programs through its four departments: Civil and Environmental, Chemical, Electrical and Computer, and Mechanical. The College also offers a PhD. The university's Carnegie Classification is a Doctoral University with moderate research activity (R-3).

\section{Relationship to Proposed ABET Criterion 3 and the Civil Engineering Program Specific Criteria}

Prior work has related the KEEN EML outcomes ${ }^{4}$ to ABET Criterion $3^{3,5}$ and demonstrated that there is significant overlap and alignment. In addition, EML can align well with the Civil Engineering Program Specific Criteria (CEPSC) and assessment of student work (Table 1). 
Table 1. Relationship between KEEN Outcomes and the Proposed ABET Criterion 3 and Civil Engineering Program Specific Criteria

\begin{tabular}{|c|c|c|c|c|}
\hline \multicolumn{5}{|c|}{ Entrepreneurial Mindset } \\
\hline \multicolumn{2}{|c|}{ Curiosity } & \multicolumn{3}{|c|}{$\begin{array}{l}\text { - demonstrate constant curiosity about our changing world } \\
\text { - explore a contrarian view of accepted solutions }\end{array}$} \\
\hline \multicolumn{2}{|l|}{ Connections } & \multicolumn{3}{|c|}{$\begin{array}{l}\text { - integrate information from many sources to gain insight } \\
\text { - assess and manage risk }\end{array}$} \\
\hline \multicolumn{2}{|l|}{ Creating value } & \multicolumn{3}{|c|}{$\begin{array}{l}\text { - identify unexpected opportunities to create extraordinary value } \\
\text { - persist through and learn from failure }\end{array}$} \\
\hline KEEN Outcome & Example Behaviors & Related Proposed ABET Criterion $3(1-7)$ & Related CEPSC & $\begin{array}{l}\text { Example Assignments for } \\
\text { Assessment }\end{array}$ \\
\hline $\begin{array}{l}\text { Engineering } \\
\text { thought and } \\
\text { action }\end{array}$ & $\begin{array}{l}\text { - Apply creative thinking to } \\
\text { ambiguous problems } \\
\text { - Apply systems thinking to } \\
\text { complex problems } \\
\text { - Evaluate technical } \\
\text { feasibility and economic } \\
\text { drivers } \\
\text { - Examine societal and } \\
\text { individual needs }\end{array}$ & $\begin{array}{l}\text { (1) an ability to identify, formulate, and solve } \\
\text { complex engineering problems by applying } \\
\text { principles of engineering, science, and } \\
\text { mathematics } \\
\text { (2) an ability to apply the engineering design } \\
\text { process to produce solutions that meet specified } \\
\text { needs with consideration for public health and } \\
\text { safety, and global, cultural, social, } \\
\text { environmental, economic, and other factors as } \\
\text { appropriate to the discipline } \\
\text { (3) An ability to develop and conduct appropriate } \\
\text { experimentation, analyze and interpret data, and } \\
\text { use engineering judgment to draw conclusions }\end{array}$ & $\begin{array}{l}\text { apply knowledge of mathematics } \\
\text {... and at least one additional area } \\
\text { of basic science; apply probability } \\
\text { and statistics...; analyze and solve } \\
\text { problems...; conduct } \\
\text { experiments... and analyze and } \\
\text { interpret the... data; design a } \\
\text { system, component, or process...; } \\
\text { include principles of } \\
\text { sustainability in design }\end{array}$ & $\begin{array}{l}\text { Capstone design report that } \\
\text { utilizes Envision }{ }^{6} \text { to score } \\
\text { sustainability; any open-ended } \\
\text { assignment that requires } \\
\text { creative solutions; engineering } \\
\text { economics problems that } \\
\text { determine the effect of civil } \\
\text { engineering infrastructure on } \\
\text { trade and economic growth }\end{array}$ \\
\hline Collaboration & $\begin{array}{l}\text { - Form and work in teams } \\
\text { - Understand the motivations } \\
\text { and perspectives of others }\end{array}$ & $\begin{array}{l}\text { (7) an ability to function effectively as a member } \\
\text { or leader of a team that establishes goals, plans } \\
\text { tasks, meets deadlines, and creates a } \\
\text { collaborative and inclusive environment }\end{array}$ & & $\begin{array}{l}\text { Peer evaluations of team } \\
\text { members in group assignments; } \\
\text { CATME }^{7} \text { evaluations }\end{array}$ \\
\hline Communication & $\begin{array}{l}\text { - } \text { Convey engineering } \\
\text { solutions in economic terms } \\
\text { - } \text { Substantiate claims with } \\
\text { data and facts }\end{array}$ & $\begin{array}{l}\text { (4) an ability to communicate effectively with a } \\
\text { range of audiences }\end{array}$ & $\begin{array}{l}\text { explain basic concepts in project } \\
\text { management, business, and public } \\
\text { policy }\end{array}$ & $\begin{array}{l}\text { Develop business canvas }{ }^{8} \text { for } \\
\text { student group in capstone } \\
\text { design and present to class; } \\
\text { develop value proposition } \\
\text { canvas }^{8} \text { for experiment } \\
\text { designed in soil mechanics }\end{array}$ \\
\hline Character & $\begin{array}{l}\text { - Identify personal passions } \\
\text { and a plan for professional } \\
\text { development } \\
\text { - Fulfill commitments in a } \\
\text { timely manner } \\
\text { - Discern and pursue ethical } \\
\text { practices } \\
\text { - Contribute to society as an } \\
\text { active citizen }\end{array}$ & $\begin{array}{l}\text { (5) an ability to recognize ethical and } \\
\text { professional responsibilities in engineering } \\
\text { situations and make informed judgments, which } \\
\text { must consider the impact of engineering } \\
\text { solutions in global, economic, environmental, } \\
\text { and societal contexts } \\
\text { (6) an ability to recognize the ongoing need to } \\
\text { acquire new knowledge, to choose appropriate } \\
\text { learning strategies, and to apply this knowledge }\end{array}$ & $\begin{array}{l}\text { explain basic concepts in } \\
\text { leadership; analyze issues in } \\
\text { professional ethics; and explain } \\
\text { the importance of professional } \\
\text { licensure }\end{array}$ & $\begin{array}{l}\text { Develop professional } \\
\text { development plan; analyze } \\
\text { ethics cases from ASCE; track } \\
\text { number of students involved in } \\
\text { service and volunteer activities }\end{array}$ \\
\hline
\end{tabular}




\section{Entrepreneurially Minded Learning in the Civil Engineering Curriculum}

The ultimate goal of the CEE Department is to weave EML into the curriculum across all four years providing multiple contexts and reinforcement for EML principles. A summary of what classes include EML, as well as the extra and co-curricular opportunities available to students are provided in Table 2. It important to note that the depth, complexity, and duration of the EML activities vary greatly from course to course; thus some explanations for assignments and activities are more detailed than others.

Freshman Year

All freshmen in the College of Engineering participate in EGR 1200 Engineering Interdisciplinary Design Project 1. This three credit course meets twice a week for 75 minutes. There are approximately 50 students in each section of this course. EGR 1200, which is offered in the fall, is broken into two parts:

- First seven weeks are a general introduction to engineering

- Second seven weeks are an interdisciplinary project

The first seven weeks of EGR 1200 includes the ICE Challenge. This challenge, which is coordinated through the Innovation, Creativity, and Entrepreneurship (ICE) institute at Villanova University, is a required assignment for all first year students in the School of Business, College of Engineering, and College of Nursing. Students propose and pitch an idea and the top teams earn prizes and the opportunity to pitch their idea at the ICE Challenge IdeaBounce ${ }^{\circledR}$. Each team, comprised of three to five students, makes a two-minute video to sell their idea for a product or service. The students are encouraged to address three key items in their videos: what, so what, now what. The top three teams win t-shirts and the top two teams pitch their idea at the IdeaBounce ${ }^{\circledR}$. The top five finalists win $\$ 100$ gift cards to be used at the University Book Store. The students are judged on three criteria: clarity of the idea, passion in the presentation, and the request for assistance.

The opportunity exists to infuse EML into the interdisciplinary projects that comprise the second half of the course. In addition, more rigorous assessment should be implemented. The ICE Challenge addresses two of the three Cs by requiring students to identify opportunities and brainstorm ideas (curiosity) and identify opportunities to create value and the potential customers (creating value). The groups that have been successful in the past have also made connections by determining if there is a need for their product by performing research. The KEEN outcomes for this activity are for students to demonstrate curiosity, integrate information, identify opportunities, apply creative thinking, and convey a solution. In the past, the five degree programs have not been eager to use the assessment of student work in freshmen classes as part of their assessment practices for ABET accreditation; however, assessing the student work would provide interesting longitudinal data on how students improved during their time at Villanova. 
Table 2. Summary of Classes with EML in the Civil Engineering Curriculum

\begin{tabular}{|c|c|c|c|}
\hline Class Name & Semester & $\begin{array}{l}\text { Status of EML } \\
\text { Implementation }\end{array}$ & Notes \\
\hline \multicolumn{4}{|c|}{ Freshmen } \\
\hline $\begin{array}{l}\text { EGR } 1200 \text { Egr. Interdisciplinary Project } \\
\text { I }\end{array}$ & Fall & $\begin{array}{l}\text { One } \\
\text { project/assignment }\end{array}$ & \multirow{2}{*}{$\begin{array}{l}\text { Projects that include } \\
\text { EML are under } \\
\text { development }\end{array}$} \\
\hline $\begin{array}{l}\text { EGR } 1205 \text { Egr. Interdisciplinary Project } \\
\text { II }\end{array}$ & Spring & Future & \\
\hline \multicolumn{4}{|c|}{ Sophomore } \\
\hline GLY 2805 Geology for Engineers & Fall & Two assignments & \\
\hline $\begin{array}{l}\text { CEE } 2105 \text { Mechanics I: Fundamental } \\
\text { Behavior }\end{array}$ & Fall & Three assignments & \\
\hline $\begin{array}{l}\text { CEE } 2106 \text { Mechanics II: Material } \\
\text { Behavior }\end{array}$ & Spring & $\begin{array}{l}\text { Multiple in- and out-of } \\
\text { class assignments }\end{array}$ & \\
\hline \multicolumn{4}{|l|}{ Serar } \\
\hline CEE 3705 Engineering Economics & Fall & One assignment & \\
\hline CEE 3901 Soil Mechanics Lab & Spring & One assignment & \\
\hline \multicolumn{4}{|c|}{ Senior } \\
\hline CEE 4602 Professional Practice in CEE & Fall & Future & $\begin{array}{l}\text { Multiple } \\
\text { opportunities exist } \\
\text { to incorporate EML } \\
\text { into this course }\end{array}$ \\
\hline CEE 4226 Transportation System Design & Fall & One assignment & $\begin{array}{l}\text { One of six possible } \\
\text { senior level elective } \\
\text { (students must } \\
\text { choose three) }\end{array}$ \\
\hline CEE 4606 Capstone Design & Spring & Future & $\begin{array}{l}\text { Multiple } \\
\text { opportunities exist } \\
\text { to incorporate EML } \\
\text { into this course }\end{array}$ \\
\hline \multicolumn{4}{|c|}{$\begin{array}{ll}\text { Extra and Co-Curricular Opportunities } \\
\end{array}$} \\
\hline Engineering Entrepreneurship Minor & \multicolumn{3}{|c|}{$\begin{array}{l}\text { Accelerated summer and traditional semester programs } \\
\text { available }\end{array}$} \\
\hline $\begin{array}{l}\text { Villanova Summer Innovation Incubator } \\
\text { (VSII) }\end{array}$ & \multicolumn{3}{|c|}{$\begin{array}{l}\text { Competitive summer program to work in teams and } \\
\text { develop a product or service }\end{array}$} \\
\hline 24HR Imagination Quest & \multicolumn{3}{|c|}{$\begin{array}{l}\text { Multidisciplinary teams create presentations and prototypes } \\
\text { that are presented at a trade show }\end{array}$} \\
\hline $\begin{array}{l}\text { Villanova Student Entrepreneurship } \\
\text { Competition (VSEC) }\end{array}$ & \multicolumn{3}{|c|}{$\begin{array}{l}\text { A three-month long campus-wide competition where } \\
\text { students create unique ideas around making the world a } \\
\text { better place }\end{array}$} \\
\hline E-Ship Workshops and Hackathons & \multicolumn{3}{|c|}{$\begin{array}{l}\text { Workshops and competitions (hackathons) are provided } \\
\text { throughout the year on a variety of hands-on skills }\end{array}$} \\
\hline
\end{tabular}

\section{Sophomore Year}

Three courses in the sophomore year have integrated EML into the curriculum: GLY 2805 Geology for Engineers, CEE 2105 Mechanics I, and CEE 2106 Mechanics II. CEE 2105 and CEE 2106 are part of a three course mechanics sequence (i.e. CEE 2105 Mechanics I, CEE 2016 
Mechanics II, and CEE 3107 Mechanics III) $)^{9}$. Within the CEE curriculum, this is the most robust year for EML integration.

\section{GLY 2805 Geology for Engineers}

Geology for Engineers (GLY 2805) is a required course for Civil Engineering students. The three credit class meets twice a week for 75 minutes. The course is taught in two sections with approximately 30 students in each section. Over the last two years, GLY 2805 has been converted from a traditional lecture format to an inverted (flipped) format. These significant changes to the course allowed for development of several new in-class activities, including an EML activity.

An EML activity, titled "Geology in the News," was performed on the first and last days of the course to foster and maintain student interest in geology and its relevance to engineering. To start the activity, students were instructed to form groups of four to five. Then, each group was assigned two generic news headlines that featured stories related to geology (e.g. "Scientists warn Yellowstone supervolcano could kill millions," "Damage from sinking land costing California billions”). Students then were allowed to use any internet-capable device to investigate the stories behind the headlines and discuss them with their group members. Most students preferred to use their smartphones. After performing brief research for both headlines $(\sim$ 5 - 10 minutes), each group discussed and summarized the stories behind each headline and chose one to focus on for the rest of the activity. Then, each group was asked to identify opportunities for improvement, to solve a problem, and/or address a common need related to the headline they chose. Students were also asked to discuss within their groups whether they believed the story represented legitimate concerns founded on science or was a case of public misconception. After identifying opportunities, the students brainstormed potential solutions (at least five), and were strongly encouraged to think outside the box without considering technical limitations. The groups chose their favorite idea and were given 10 minutes to develop a twominute pitch and decide how the pitch would be delivered. Finally, each group pitched their idea to the rest of the class. The students were allowed to use the board and/or any figures they had drawn. Each group then voted for their favorite idea and pitch (other than their own group's pitch). For five to six groups, the total activity took 35 to 40 minutes to complete.

This assignment addresses the three Cs by requiring students to identify opportunities and brainstorm ideas (curiosity), perform research and integrate information from many sources to gain insight (connections); and identify opportunities to create value and the potential customers (creating value). The KEEN outcomes for this activity are for students to demonstrate curiosity, integrate information, identify opportunities, apply creative thinking, and convey a solution.

An anonymous survey was administered after the activity on both the first and last days of class to evaluate the entrepreneurial aspects and identify areas for improvement. The survey questions were: "For the activity that you just completed, do you feel that you...

1) Exercised curiosity about surrounding world and topics related to geology?

2) Identified opportunities for improvement, to solve a problem, and/or address a common need? 
3) Brainstormed and thought outside of the box to explore novel ideas/solutions?

4) Integrated information from various sources to gain insight regarding the problem?

5) For the first class: Identified potential topics or directions for your term paper that you are interested in learning more about?

For the last class: Made connections with the content we have covered in this course (or your term paper)?”

The answer choices were "Yes," "No," or "Maybe.” The feedback from the students regarding this activity was very positive. The results of the survey regarding the students perceptions of the activity on the first day were: $96 \%$ exercised curiosity, 89\% identified opportunities, 93\% thought outside the box, and $80 \%$ integrated information from various sources. In addition, 55\% of the students left the first day of class with potential ideas for their term papers. Similar survey results were obtained on the last day of class. When the activity was performed on the last day of class, $85 \%$ of the students were able to tie the ideas in the headlines back to the course content they had learned throughout the semester.

EML was also incorporated into an assignment on construction materials. Prior to coming to class, the students had already watched a video lecture on construction materials. In this assignment, students were broken into groups and each group was assigned a different mineral resource. The students engage in role playing by envisioning that they recently purchased an active mine site. They are asked to perform research to learn about their mineral resource and the associated mining process (from mining the minerals through production of materials) by answering the following questions:

- What are the key activities at your mine? Potential challenges?

- What resources do you need to continue to produce the mineral?

- Who are your customer segments?

- Which other group might you partner with to expand your market?

These questions are based off of a Business Model Canvas created by Strategyzer ${ }^{8}$. This assignment is focused on making connections and creating value.

The Geology in the News assignment was very effective in setting a tone in the class that geology can be exciting. In the past, student perceptions coming into the class were poor. In the future, the second assignment on construction materials will utilize the Business Model Canvas directly so that students are better able to see the value that is created by these products. The use of the canvas in this class is important because it will be incorporated in capstone classes in the future.

CEE 2105 Mechanics I: Fundamental Behavior

CEE 2105 is a four credit course offered fall semester sophomore year and co-taught by two CEE faculty. The course content includes topics traditionally covered in a statics course, together with the study of column buckling and the uniaxial stress-strain behavior of carbon steel. The class is delivered using an inverted format where students are required to watch prerecorded lectures before class, and in-class time is largely spent on problem solving and application. In a given week, there are three 50 minute meetings and one 165 minute "flex" period. A central part 
of the class is the utilization of three "overarching” problems (OAPs) ${ }^{10}$, which are a comprehensive design or analysis problem that involves unification of numerous basic concepts.

EML concepts are introduced into each of three OAPs, which include the study of a steel truss bridge, earth dam, and steel water tower. The EML content includes emphasis on illustrating that economic viability, customer value, technical feasibility, and social benefit are essential considerations of engineering design. Students evaluate and communicate an engineering solution to the given OAP in terms of these four considerations (technical feasibility, customer value, societal benefits, and economic viability). In evaluating their solution, students consider the current state of infrastructure and technologies in the United States, need levels in the United States and developing countries, and design and economic constraints in developing countries. This assignment allows student to compare and contrast feasibility, value, engineering, and economic constraints in the United States to the developing world.

These assignments address all of the three Cs. Curiosity is stimulated by exposing students to opportunities created by the current state of domestic bridge infrastructure as well as infrastructure conditions in developing countries. Connections are forged by realizing the need to improve on existing technologies related to building and maintaining better domestic infrastructure as well as providing for the same in the developing world. Lastly, the students learn that their engineering skills can be creatively used to improve the lives of others, or create value.

The success of EML in this class is assessed using a survey similar to the one described for the Geology in the News assignment. This survey is offered before and after each OAP. In addition, supplementary questions regarding EML are included on the course evaluation given at the end of the semester. The students consistently respond positively to their learned abilities related to EML skills such as exercising creativity and curiosity, recognizing new opportunities and value creation, assessing risk and economic drivers, and anticipating technical developments by interpretation of societal and economic needs.

CEE 2106 Mechanics II: Material Behavior

CEE 2106 is 4 credits and is offered spring semester sophomore year. The course content includes topics traditionally covered in a mechanics of solids course together with the study of engineering materials, including concrete, timber, masonry, composites and asphalt. Like CEE 2105, it is co-taught, delivered in an inverted format, meets four times per week and uses OAPs as a learning tool in showing how multiple topics in mechanics and material behavior are related through the comprehensive study of an engineering system.

Over the first half semester several creative thinking exercises are introduced in an effort to stimulate curiosity via conceptual improvements to the behavior of existing materials and structural systems. These exercises represent open-ended questions integrated into the lecture to allow students to explore the topic being discussed from a different perspective, one that is unrestrictive. For example, during the study of concrete, students are asked "what are the ideal properties for aggregate; a binding material; or, in a more general sense, what would be the ideal properties of the perfect construction material?” During the study of bending stress and 
deformation, students are asked to imagine how stresses and deformations related to gravity load and flexure can be reduced. The behavior of prestressed concrete is noted as an example where tension in the concrete is eliminated by introducing a negative bending moment. The concept of 'disruptive technology' is introduced, with prestressed concrete cited as an example. These exercises address all three Cs.

The second half of the course allows for the exploration of creative thinking in more detail. Students submit a series of assignments focused on developing engineering thought and action. Students start with the selection of a new or novel structural system that has advantages over existing technology, as well as barriers to its acceptance. This is followed by a general economic investigation where the initial target market is identified, as well as new and future markets. The conclusion is a schematic representation of the novel system, describing its advantages over existing technologies, economic viability, and future use. Students present their system to the class using PowerPoint. Example student novel systems include Brick-Lock, Diamond Aggregate Concrete, Carbon Fiber Radio Tower Abutment, Nylon-Concrete System, Composite Carbon Fiber Microlattice, Solar Paneled Bridge, and Incan Grass Fibers.

These assignments address the three Cs. Through these EML exercises students understand that there is much opportunity for improvement to current technologies related to engineering materials and structural systems. They are encouraged to creatively conceive of novel solutions to these opportunities, and, importantly, expand their thinking beyond existing technological limits. Connections are made by proposing new technologies that obey the basic science of engineering materials and mechanics but in new and innovative ways. Through recognizing where opportunity exists, and proposing creative solutions rooted in science and innovation, new value is created where previously there was none.

Assessment related to EML content is collected in the form of faculty evaluation of the final presentations, as well as supplementary questions on the end of the semester course evaluation. Like CEE 2105, students consistently respond positively to their learned abilities related to EML skills such as exercising creativity and curiosity, recognizing new opportunities and value creation, assessing risk and economic drivers, and anticipating technical developments by interpretation of societal and economic needs.

\section{Junior Year}

Currently, two classes in the junior year incorporate EML activities to varying degrees: CEE 3705 Engineering Economics and CEE 3901 Soil Mechanics Laboratory.

CEE 3705 Engineering Economics

CEE 3705 is taught in the fall semester and meets twice a week for 75 minutes. Most of the students in the class are juniors, however, students that have studied abroad as juniors often take this class as seniors. Engineering Economics is a logical place to focus on how civil engineers create value.

The instructor in this class has utilized various guest speakers to discuss entrepreneurship and has focused several homework problem on the Panama Canal Expansion project. This expansion, which cost more than $\$ 5$ billion, doubled the capacity of the canal. These homework assignments 
ask the students to relate how this massive project is affecting world trade. This students analyze shipping routes (e.g. https://www.marinetraffic.com) and estimate how the canal expansion will affect nearby ports in Philadelphia, PA and Wilmington, DE. These assignments are focused on how civil engineering infrastructure creates value by having the students convey this engineering solution in economic terms.

Presently, no assessment is performed in this class related to EML. However, work from this class is used to assess ABET outcomes. The two assessment goals could be met with a single assignment.

CEE 3901 Soil Mechanics Laboratory

CEE 3901 is a co-requisite of CEE 3801 Soil Mechanics that is typically taken in spring of junior year. The laboratory lasts for approximately three hours and the students attend every other week. The typical class size is 12 to 15 students with lab group sizes of 3 to 4 students. In the second laboratory session, students perform mechanical sieve and hydrometer analysis (ASTM D422) and liquid and plastic limit tests (ASTM D4318) to classify soils using soil classification systems (e.g. Unified Soil Classification System). However, students typically express frustration with the standard test procedures to measure the liquid and plastic limits. To harness this frustration into something useful, an EML activity was implemented encouraging students to explore and design alternative test methods.

After completing the liquid and plastic limit tests during their laboratory session, the students were asked to complete an EML assignment outside of class and then present the results to the class in the next laboratory session. In the assignment, students were asked to brainstorm alternative techniques that could be used to find the liquid and plastic limits. From their brainstormed ideas, each group selected one method/product/technique they wanted to develop further. For their selected product, the groups determined what market exists for the product and described the size of the potential market. Students came to the next class (two weeks later) with 20 copies of a one page description of their new method/product/technique to find the liquid and plastic limits. Each group was required to include a sketch of any new equipment, an estimated price, and the potential market. In addition, each group delivered an "elevator pitch" for their product(s) ( $<2$ minutes). The class then voted for the best product.

This assignment addresses the 3Cs by requiring students to identify opportunities and brainstorm ideas (curiosity), investigate the market and perform research (connections); and identify customers and develop a value proposition (creating value). The KEEN outcomes for this activity are for students to explore a contrarian view of an accepted solution, integrate information, identify opportunities, apply creative thinking, investigate the market, evaluate value and feasibility, and convey a solution.

This assignment has been used to assess a student's ability to design an experiment (ABET Criterion $3 \mathrm{~b}$ under the current criteria), so assessment is being performed on this assignment. However, although the proposed ABET criteria no longer requires students to design an experiment, the assessment of this assignment could still continue. Instructor observations indicated that the students did not take the assignment seriously enough and the solutions were 
not well-conceived. More weight will be given to this assignment in the future to highlight its importance.

\section{Senior Year}

Currently only one class, CEE 4226 Transportation Systems Design, includes an EML related assignment. CEE 4226 is one of six possible electives students can take senior year (they must choose three). During this class students visit the Cave Automatic Virtual Environment (CAVE) which uses immersive video for telepresence applications and 3D visualization to demonstrate different transportation designs. After visiting the CAVE, the students are asked to provide an innovative research idea on how the CAVE could be applied to promote pedestrian safety, especially for children. This assignment is related to the making connections, demonstrating curiosity, and creating value.

CEE 4602 Professional Practice in CEE and CEE 4606 Capstone Design present many opportunities for incorporating EML. These classes have been slow to implement EML because the instructors that are responsible for them have not completed the EML training. However, it anticipated that the EML Champion for the department will work with the faculty in incorporating EML into these courses. Both CEE 4602 and 4606 have open-ended assignments that require students to consider the economic impact of their solutions. Some specific ways that EML could be incorporated into CEE 4602 are:

- Create/update a professional development plan

- Develop a business plan for their "consulting group”

- Continue to have the students analyze ethics cases

Some specific ways that EML could be incorporated into CEE 4606 are:

- Have the students explicitly go through a brain storming exercise to develop solutions

- Use Envision to consider social, environmental, and economic impacts of their designs (relates directly to CEPSC)

These classes are already vigorously assessed, so it would not be burdensome to the faculty to ask them to assess the success of these assignments.

Co- and Extracurricular Opportunities

Engineering Entrepreneurship Minor

The Engineering Entrepreneurship Minor is open to all engineering students. This is the most popular minor for engineering students with approximately 80 (10\% of the students in the college) students enrolled. Sixteen credits over eight classes are required to complete the minor. The classes emphasize the following topics: creativity, innovation, opportunity analysis, new product/service/process ideation and development, intellectual property, project management, prototyping, basic accounting and finance concepts, project funding, product launching, new concept marketing, risk management, and team development. Students enter the minor as sophomores and are working with a team by the end of sophomore year to develop marketable products and services. In the summer of 2017, an accelerated summer version of the Engineering 
Entrepreneurship Minor will be launched. This summer program will be available to students within and eventually outside of Villanova University.

Villanova Summer Innovation Incubator (VSII)

VSII is a summer campus-based incubator program supported by the Harris Foundation. VSII funds three to four self-directed, multidisciplinary teams who develop solutions over a twomonth period to address real-world challenges. The student teams meet weekly with faculty mentors; however, the students are responsible for all aspects of their projects from initial concept design to delivery of a prototype. The students receive stipends, housing, and meals as well as a project budget and access to the University’s labs and facilities.

\section{HR Imagination Quest}

Promoted as a combination of The Amazing Race, Shark Tank, The Apprentice, and Fear Factor, the Imagination Quest is a fast-paced team competition taking place over a 24 hour period, from Saturday at noon to Sunday at noon. During the event, multidisciplinary teams are constantly on the move and feverishly working on presentations and prototypes, all leading up to the trade show and a big final presentation Shark Tank style.

Villanova Student Entrepreneurship Competition (VSEC)

The Villanova Student Entrepreneurship Competition (VSEC) is a three-month long, campuswide student-only competition designed to allow students to create unique ideas around making the world a better place. The annual competition was founded in 2009 by two graduate engineering students, and attracts hundreds of students and judges. The competition is designed to provide a realistic, modern entrepreneurial environment in which students are able to put together comprehensive ideas and to understand, first-hand, the process of entrepreneurship in today's rapidly changing world. Though business development is not the goal of the competition, support services are in place for those finalists who do intend to develop their ideas further as well as for those who take their competitive ideas to national competitions.

E-Ship Workshops and Hackathons

Engineering entrepreneurs have an advantage over others in that they are able to design and build working prototypes of their concepts. A working prototype greatly increases the ability to communicate the idea of a product, service or process. To increase the ability of student teams to produce quality prototypes, a number of workshops and competitions (hackathons) are provided throughout the year on a variety of hands-on skills such as soldering, machine shop tools, Arduino sensor systems, Raspberry Pi, Android programming, Solidworks, and 3D printing.

\section{Opportunities for Growth}

While EML is suitable for inclusion in all courses, several opportunities for growth are apparent. The inclusion of EML into the mini-projects associated with the freshmen required courses (EGR 1200 and 1205) and in the discipline-specific sections of EGR 1205 would ensure that students appreciate that EML is a critical part of the learning process.

In senior year, both CEE 4602 Professional Practice in CEE and CEE 4606 Capstone Design are natural fits for EML. In CEE 4602 students focus on feasibility studies and professional issues related to civil engineering such as project management, public policy, business, leadership, 
ethics, and professional licensure. EML could provide a framework to explore these topics in a more cohesive, exciting manner.

More rigorous assessment of whether the KEEN outcomes are being achieved is needed.

Currently, the assessment that is performed relies on surveys as opposed to evaluation of student work.

\section{References}

1. Gerhart, A., Carpenter, D., Fletcher, R., and Meyer, E. (2014). “Combining DisciplineSpecific Introduction to Engineering Courses into a Single Multi-Disciplinary Course to Foster the Entrepreneurial Mindset with Entrepreneurial Minded Learning,” Proceedings of the $121^{\text {st }}$ ASEE Annual Conference and Exposition, Indianapolis, IN, June 15-18.

2. Thoroughman, K., Hruschka, A., and Widder, P. (2014). "Engineering Virtual Studio: KEEN Modules to Foster Entrepreneurial Mindset in an Integrative, First/Second Year Online Course," Proceedings of the $121^{\text {st }}$ ASEE Annual Conference and Exposition, Indianapolis, IN, June 15-18.

3. Peterson, O., Jordan, W., and Radharamanan, R. (2012). "Proposed KEEN Initiative Framework for Entrepreneurial Mindedness in Engineering Education,” Proceedings of the $119^{\text {th }}$ ASEE Annual Conference and Exposition, San Antonio, TX, June 10-13.

4. KEEN outcomes, http://www.kffdn.org/files/keen-student-outcomes.pdf.

5. Duval-Couetil, N., Kisenwether, E., Tranquillo, J., and Wheadon, J. (2015). "Exploring the Intersection of Entrepeneurship Education and ABET Accreditation Criteria,” The Journal of Engineering Entrepreneurship, Vol. 6, No. 2, pp. 44-57.

6. Institute for Sustainable Infrastructure (ISI) Envision, https://sustainableinfrastructure.org/.

7. CATME Team Maker, https://info.catme.org/.

8. Strategyzer Canvases, https://strategyzer.com/canvas.

9. Gross, S.P., and Dinehart, D.W. (2015). "Flexible Periods Allow for Combined Analytical and Laboratory Experiences Within an Introductory Mechanics Course," Proceedings of the $122^{\text {nd }}$ ASEE Annual Conference and Exposition, Seattle, WA, June 14-17.

10. Gross, S.P., Dinehart, D.W., Yost, J.R., and Radlinska, A. (2011). “Overarching Problems in Sophomore Mechanics Courses," Proceedings of the $118^{\text {th }}$ ASEE Annual Conference and Exposition, Vancouver, BC, June 25-29.

\section{Acknowledgements}

The authors would like to thank the Kern Family Foundation and Edmond Dougherty, the director of Engineering Entrepreneurship and Amanda Kelly, Program Coordinator for Kern Entrepreneurship Program for their assistance and commitment to EML. 